\title{
Teoria da empatia e modelo praxiológico da comunicação: aproximações (improváveis) entre Flusser e Quéré
}

\section{Leticia Cantarela Matheus}

Doutora; Universidade do Estado do Rio de Janeiro, Rio de Janeiro, RJ, Brasil

leticia_matheus@yahoo.com.br

\section{Raquel Dornelas}

Doutoranda; Universidade do Estado do Rio de Janeiro, Rio de Janeiro, RJ, Brasil raqueldornelas@gmail.com

\begin{abstract}
Resumo
O ensaio tem como objetivo fazer uma aproximação entre a noção de empatia na visão de Vilém Flusser e o modelo praxiológico da comunicação, elaborado por Louis Quéré. Tais definições são aqui apresentadas dentro de perspectivas que trabalham a importância da intersubjetividade, da interação entre humanos e do processo de constituição do indivíduo a partir de um movimento de inclinação em direção à alteridade. Nesse sentido, teóricos de escolas e temporalidades distintas são acionados no intuito de mostrar como uma "teoria da empatia" pode ser utilizada como arcabouço teórico contributivo ao modelo praxiológico da comunicação. Conclui-se que, a despeito das diferenças conceituais, ambos os teóricos veem, na relação com a alteridade e na intersubjetividade, o amálgama da experiência humana.
\end{abstract}

\section{Palavras-chave}

Empatia. Alteridade. Modelo praxiológico. Intersubjetividade.

\section{Introdução}

No senso comum, a palavra "empatia" remete ao ato de se colocar no lugar do outro. A raiz grega do vocábulo (empátheia $=\mathrm{em} /$ no sentimento) sugere a ideia de o sujeito se inserir no sentimento do outro e no que está sendo vivido ele. Falar de empatia, portanto, implicaria falar em alteridade, ou seja, em uma postura frente ao outro com o qual me relaciono. A etimologia da palavra revela nuances mais interessantes. Uma das correntes 
que explica a origem do termo o aproxima da noção de pathos, suscetível à afecção pela situação vivida por uma pessoa. E, diferentemente de simpatia a empatia seria uma atitude objetiva, reflexiva e crítica, (DICIONÁRIO DE CHILE, 1998).

Empatia e alteridade são temáticas que atravessam a obra do filósofo Vilém Flusser (1994a, 1994b, 1998, 2012). Sendo um teórico que transitou por diversas áreas, como Filosofia, Arte, Religião e Linguagem, Flusser comumente trabalha as duas noções na sua produção diversificada. $\mathrm{O}$ autor destaca que a empatia possui uma dupla face: a identificação e o confronto com a diferença. Assim, o pensamento de Flusser foge da inocente visão de entender relações empáticas como algo necessariamente permeado por harmonia e consenso. Ainda que o autor não entre no debate etimológico do vocábulo, é possível perceber que sua definição vai ao encontro das raízes do termo, ao propor uma agência dos sujeitos que se relacionam não apenas movidos por instintos, mas que deliberadamente atuam no mundo em comum. Nesse sentido, empatia é uma atitude, um gesto de se inclinar em direção ao outro.

Flusser $(2002,2007)$ afirma que uma Filosofia da Comunicação deve sempre levar em conta os confrontos, a mutabilidade e a diversidade dos atores. Em outras palavras, a comunicação teria um caráter empático por natureza e, por isso mesmo, envolveria interações atravessadas pelas fronteiras entre os sujeitos, suas constituições, o fato de estarmos em contínua transformação e a vivência de múltiplas temporalidades. Assim, tomando como base o pensamento do autor, podemos entender que essa diversidade de características vem à tona nas interações tanto interpessoais diretas quanto mediadas. No movimento de me lançar em direção ao mundo do outro, a fim de compreendê-lo e compreender a situação na qual essa fala está inserida, há um compartilhamento de experiências distintas que nos constituem enquanto sujeitos e nos ajudam a entender quem somos por meio desse exercício de "outramento". Essa trilha reflexiva que atravessa o pensamento de Flusser pode ser entendida como uma "Teoria da Empatia" para a qual contribuíram também outros filósofos, tais como Lou Agosta (2014) e Adriana Cavarero (2016).

Realizando uma leitura da obra flusseriana, com destaque para a proposta do caráter fundamentalmente relacional entre os sujeitos, propomos um diálogo entre o pensamento do autor e do sociólogo francês Louis Quéré (2018), especificamente a respeito do seu "modelo praxiológico da comunicação" (1991). Tal proposta busca conexões e fronteiras entre ambas perspectivas, além de um exercício intelectual sobre a empatia. Apesar de não serem comumente tratados como complementares, acreditamos que o tensionamento entre 
os dois permite pensar os cruzamentos possíveis e refletir sobre aspectos importantes para a compreensão da comunicação como processo - relacional e empático.

Esperamos, dessa forma, estabelecer algumas relações improváveis entre os dois autores, em torno de abordagens próprias sobre a alteridade, a partir da ênfase na noção de empatia. Entendermos que esta noção permite pensar perspectivas dialógicas na Comunicação, especialmente no exercício de criação de sujeitos e sociabilidades possíveis.

\section{Por uma teoria da empatia}

A importância dada a Flusser para a temática da empatia pode ser, em parte, explicada pela sua biografia marcada pela diversidade de conexões de uma vida em permanente trânsito. Flusser, nascido em Praga e judeu, foi expulso pelos nazistas e, por isso, morou por de mais de 30 anos no Brasil, morrendo na Europa. Acostumado a viver em contextos bem distintos, ele elaborou seu pensamento entendendo a cultura como um processo comunicacional em permanente fluxo.

Para destacar essa mutabilidade, o autor aciona o clássico questionamento metafórico de Heráclito: é possível se banhar no mesmo rio duas vezes? Flusser (1998) faz sua exposição respondendo que o rio continua o mesmo; o que muda é o sujeito que emerge nele. Flusser fala ainda sobre o ato de reconhecimento por aquele que ficou - que, comumente, tem uma atitude de estranhamento. Além disso, quem regressa também sente certo estranhamento do estranhamento daquele que o recebeu. Pode parecer confuso o jogo de palavras, mas Flusser parece dizer apenas que, para nos situarmos no espaço e no tempo, é imprescindível a relação com a alteridade.

Temos a capacidade tipicamente humana de ver-nos a nós próprios na situação na qual estamos. Quem está voltando para São Paulo pode servir de espelho aos que andam pelas suas ruas e largos. E pode, por sua vez, espelhar-se nos passantes que pararam repentinamente (FLUSSER, 1998, p. 164).

Assim, o reconhecimento situacional acontece na intersubjetividade comunicativa, no encontro com aqueles que estão ao redor. Para Flusser (1998), somos capazes de alterar realizações em nós e de nos reconhecer quando estamos em interação. Em quadros diferentes, nos quais estamos isolados, encapsulados, acabamos nos reificando, o que 
levaria, contraditoriamente, à perda de nossa singularidade. Portanto, nossa singularidade não se encontraria no isolamento, mas na relação.

Esse caráter interacional da construção do eu é uma importante chave de leitura para uma das obras mais curiosas e intrigantes de Flusser. Na fábula Vampyroteuthis infernalis (2012), o autor utiliza a figura de um molusco habitante de áreas profundas do Mar da Índia para mostrar como, em suas fundamentais diferenças, a criatura muito se assemelha a nós, seres humanos. A partir de um ponto de vista externo e distante (que dificilmente assumiríamos), somos capazes de enxergar nossas próprias particularidades, fraquezas e forças. Ao propor o choque com a alteridade máxima, o ser humano poderia, enfim, encontrar-se.

A despeito da barreira que nos separa, o Vampyroteuthis não é incompreensível. [...] Somos, os dois, variações do mesmo jogo com as pedrinhas da informação genética que programa toda a vida terrestre. A mesma estrutura fundamental informa nossos dois corpos. 0 seu metabolismo é o nosso. Ele ocupa uma das pontas da mesma árvore filogenética da qual nós ocupamos a outra ponta. Nossos antepassados comuns dominavam as praias primordiais por incontáveis milhões de anos. [...] Os nossos dois destinos estão co-implicados. As nossas duas memórias abrigam os mesmos dados em suas camadas profundas. Podemos reconhecer nele parte do nosso próprio estar-no-mundo (FLUSSER, 2012, p. 14).

Assim, diminuindo a barreira entre as duas espécies, Flusser propõe considerar a dimensão desse outro que tem um caráter antagônico. Talvez, assim, consigamos fazer o exercício especulativo de entender, sob essa perspectiva "fabulosa", o que seria, afinal, ser humano. É exatamente na diferença (nesse caso, radical) que nossa identidade poderia emergir. Hayles (2014) destaca como a fábula de Flusser, envolvendo o Vampyroteuthis, evidencia aspectos escondidos ou reprimidos de nossa sociedade, como a violência.

Obviamente, há uma agenda aqui que vai além da reconstrução da visão de mundo da criatura, e isso pode explicar por que Flusser quer que ele seja visto como um dos principais predadores em seu ambiente aquoso, fazendo dele um paralelo com os humanos sendo os principais predadores terrestres (HAYLES, 2014, p. 161). ${ }^{1}$

\footnotetext{
Tradução livre de "Obviously, there is an agenda here that goes beyond reconstructing the worldview of the creature, and this may explain why Flusser wants him to be seen as one of the top predators in his aqueous environment, making him parallel to humans as top terrestrial predators".
} 
Tal discussão conduz à questão da empatia. Se empatia é, em um sentido generalista, colocar-se no lugar do outro, podemos perceber como o posicionamento do humano, em uma realidade fabulosa, pode ter um valor heurístico. 0 deslocamento para uma vivência fictícia colocaria diante de nós questões que a ciência, por exemplo, não consegue responder. 0 convite especulativo acaba, de alguma forma, ajudando a entendermos as particularidades humanas.

Em um dos seus últimos escritos, Vom Subjektzum Projekt, Flusser (1994b) reflete sobre o fenômeno da sociedade em rede. Na visão do autor, tal formatação social faz com que os indivíduos não consigam mais viver isolados, já que estão em conexões cada vez mais ininterruptas. A coexistência com aquele que é diferente permitiria refletir, assim, sobre a questão da alteridade - especificamente aquela que faz encarar o que o autor chama de (ou o que seria uma) alteridade radical. Atualmente, os indivíduos se deparam com um mundo globalizado e com possibilidades comunicacionais muito mais amplas. De tal equação, resulta a possibilidade de coexistirmos com a diferença de forma mais intensa a partir de interações bastante diversificadas.

Mesmo que Flusser tenha pensado numa sociedade em rede anos antes da configuração atual da internet - e das mídias digitais -, sua reflexão parece mais atual do que nunca, engrossando o coro daqueles que o consideram como um autor "profético". Em Vom Subjektzum Projekt (1994b), Flusser já se referia à necessidade de se adaptar a uma rede desterritorializada, polissêmica e heterogênea, uma rede em que alteridades se chocariam permanentemente e a empatia se revelaria como uma necessidade constante.

Ainda sobre a empatia, Cavarero (2016) faz uma crítica do que ela chama de "retitude" do ser humano - a posição ereta como metáfora de uma forma de relação com a alteridade -, desenvolvendo sua tese em torno da ideia de inclinação dos sujeitos. Como figura alegórica, a autora associa a simbologia da retitude para criticar o sujeito kantiano verticalizado e a visão autonomista como marco fundador da ética humana. Em contrapartida, ela estabelece uma discussão em torno do ato de inclinar-se no intuito de defender a relação como ética fundadora dos indivíduos.

Cavarero traz para o centro do seu argumento uma tela pintada por Leonardo da Vinci, A Virgem e a criança com Santa Ana, do começo do século XVI. Ao mostrar como Maria se posiciona em relação ao filho, a autora chama a atenção para a assimetria do quadro alicerçada sob um eixo de inclinação, e para a vulnerabilidade e dependência do menino Jesus. Atrás da virgem, está Ana, completando a linha imaginária oblíqua. 
Leonardo, ao contrário, rompe com este sistema de verticalidade simétrica, apresentando uma mãe que está cara a cara com seu filho; [...]. Não só revela a vulnerabilidade da criança e sua dependência dos outros, mas também acentua a relação entre Maria e seu filho, redobrando-a através da relação entre Ana e Maria (CAVARERO, 2016, p. 99).²

A autora defende que a cena relacional revela uma ética altruísta, um contexto marcado pela dependência entre os sujeitos. A mãe, na obra, representaria justamente aquela que se dispõe ao outro. Podemos pensar ainda que o " $\mathrm{X}$ " que caracteriza a composição da imagem no Renascentismo parece, no quadro, desdobrar-se em um duplo que se desloca. Como duas dimensões simultâneas, os corpos de Ana e Maria formam dois "X", porém Maria se destaca da composição ao deslocar seu eixo. 0 movimento de inclinação seria assim uma predisposição para responder àquele que é diferente de mim. "Extrovertida, curvada, responsiva - esta postura é típica de um eu que se dobra sobre o outro, abandonando notadamente seu próprio equilíbrio" (CAVARERO, 2016, p. 105)³.

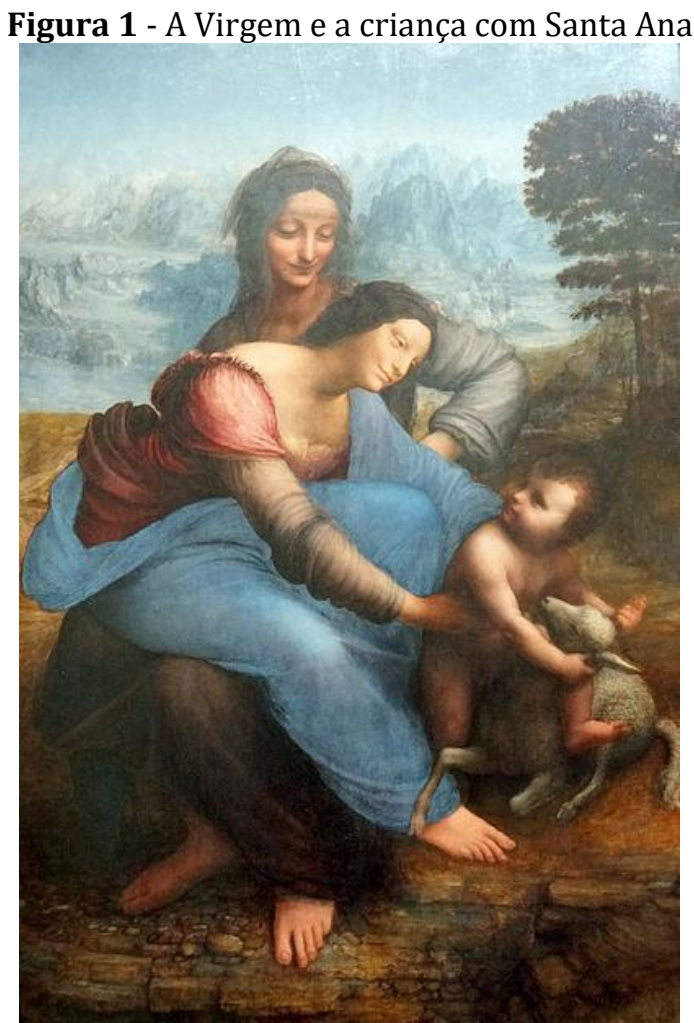

Fonte: Google Images, Leonardo da Vinci, óleo sobre madeira, 1513.

\footnotetext{
${ }^{2}$ Tradução livre de "Leonardo, by contrast, breaks with this system of symmetrical verticality, presenting a mother who is face to face with her child; [...] Not only does it foreground the child's vulnerability and his dependence on others, but it also accentuates the relationship between Mary and her son, redoubling it through the relationship between Anne and Mary".

3 Tradução livre de "Extroverted, stooped, responsive - this posture is typical of a self that bends itself over the other, conspicuously abandoning its own balance".
} 
Nesse sentido, podemos pensar que a comunicação, enquanto processo não monológico, tem a capacidade de atingir o outro e de acionar a empatia, justamente na disposição que sugestiona a inclinação entre os sujeitos. Apesar de propor uma desconstrução desse "eu" em direção ao "outro", Cavarero (2016) não defende a fragmentação de individualidades, mas a formação de múltiplas singularidades no movimento de inclinação para aquele que está além de mim. É no gesto de se inclinar para a criança que Maria encontra sua individualidade, assim como é no aspecto relacional que o sujeito se constrói.

Lou Agosta (2014) também traz uma abordagem sobre a temática da empatia, mapeando o conceito no escopo da filosofia, passando por Kant, Husserl e Lipps. O autor apresenta quatro esferas da manifestação da empatia: a receptividade, o entendimento, a interpretação e o discurso. Esses elementos não seriam estanques, mas poderiam interpenetrar no circuito um do outro - simultaneamente ou sequencialmente. Assim, percebemos que o autor imputa ao processo de empatia um caráter, ao mesmo tempo, passivo e ativo. Lou Agosta argumenta, ainda, que ser empático é adotar "uma forma de responsividade ótima que inclui tanto o ouvir quanto o responder no comportamento e no discurso" (AGOSTA, 2014, p. 6) ${ }^{4}$.

Na perspectiva do autor, a empatia é permeada pela ficcionalidade. Isso porque um indivíduo nunca poderá estar, de fato, no lugar do outro, mas isso se torna um exercício de imaginação. 0 outro será sempre uma ficção - mas uma ficção necessária para o indivíduo encontrar a própria verdade. 0 outro é a fonte da qual o sujeito social bebe a fim de perceber sentidos de existência e possibilidades de vida.

A empatia não é redutível a uma única função mental; mas se baseia em uma variedade de métodos cognitivos de interpretação, enquadramento, conceituação e formulação de alteridades, como identificação transitória, projeção, introjeção e transformações relacionadas (AGOSTA, 2014, p. 6). ${ }^{5}$

Por isso mesmo, a empatia não pode ser entendida apenas pela rubrica da concordância. Se pensarmos no termo somente sob uma ótica romântica e consensual, cairemos no risco de aplicar a noção apenas às interações harmoniosas e não conflituosas. A empatia não pode ser considerada apenas um sinônimo de altruísmo, mas sim como o ato de

\footnotetext{
4 Tradução livre de "a form of optimal responsiveness that includes both listening and responding in behavior and speech".

5 Tradução livre de "Empathy is not reducible to a single mental function; but draws on a variety of cognitive methods of interpreting, framing, conceptualizing, and formulating otherness such as transient identification, projection, introjection, and related transformations".
} 
se colocar em um outro lugar - mesmo que tal lugar nos seja estranho, desconfortável, não desejável e até mesmo inimaginável - presente também no pensamento de Flusser, como já mencionado.

Até esse ponto da discussão, percebemos como o tema da empatia está intimamente ligado a uma noção experiencial do estar com o outro, à ideia de intersubjetividade ou de subjetividades em coexistência. Portanto, tentaremos, a seguir, entender como as contribuições até aqui mencionados podem se entrecruzar, no objetivo de perceber se (e como) tais perspectivas podem contribuir para o entendimento do processo comunicacional pela perspectiva praxiológica.

\section{0 modelo praxiológico da comunicação}

Os estudos de comunicação têm sido desenvolvidos, nos últimos anos, dentro do que se pode chamar de "modelo relacional". Em linhas gerais, tal modelo se refere a um paradigma que se dedica a pensar os fenômenos comunicacionais a partir de uma ótica processual. Por meio de tal perspectiva, interlocutores, mensagem, meio e contexto são percebidos como componentes de um mesmo circuito, de um mesmo processo que deve ser considerado na sua totalidade, e não com o foco em apenas um ou dois de seus componentes, como pólos no antigo modelo matemático de emissor, canal e receptor. A perspectiva relacional teria se colocado, portanto, como forma de ultrapassar a chamada visão linear ou informacional da comunicação, que deu origem a diferentes vertentes que enfocavam majoritariamente as mídias, como, por exemplo, os antigos estudos dos chamados "meios de comunicação de massa".

Autores como Mead (1934), Habermas (1984), Hall (2003) e Braga (2006, 2011) são exemplos de importantes contribuições metodológicas e epistemológicas para a consolidação do paradigma relacional. Porém, outro autor menos citado na Comunicação, mas igualmente potente, é o sociólogo Louis Quéré. Seu modelo praxiológico foi sintetizado em uma obra de 1991, publicada no Brasil em 2018 (QUÉRÉ, 2018). De origem camponesa, o autor carrega forte herança pragmatista e da chamada Escola de Chicago, vertente norteamericana de estudos sociais.

A contribuição de Louis Quéré para a Comunicação pode ser identificada no olhar privilegiado que o autor dedica ao ato comunicacional dentro dos estudos sociológicos, entendendo-o pelo viés da interação, como prática relacional de dimensão concreta e que se desenvolve em um tempo e um espaço específicos. 0 autor busca compreender a sociedade 
como um tecido vivo, formado por sujeitos em ações contínuas e coordenadas no espaço público, relacionando-se uns com os outros e, consequentemente, interagindo com o mundo.

Quéré (2018) cunha dois termos que considera opostos: modelo praxiológico e epistemológico da comunicação. Por analogia, podemos entendê-los como aproximações aos paradigmas relacional e informacional, respectivamente. 0 modelo praxiológico traria, para os estudos em comunicação, a centralidade da prática (práxis), isto é, a interação no espaço social, evidenciando-se que os sujeitos constituem e são constituídos pela linguagem em ato. Deste modo, a perspectiva de Quéré enxerga os processos comunicacionais como dimensão formadora de toda a coletividade.

Para Quéré (2018), lançar luz sobre as interações ajuda a entender nossa capacidade de ajustamento, o que remete ao princípio da empatia. Ao interagirmos, podemos ser surpreendidos por ações e falas não esperadas, ter nossas expectativas frustradas ou superadas com relação ao outro, além de depararmo-nos com contextos não esperados. Esse cenário complexo criaria um imperativo de adequação, no instante mesmo do ato comunicacional. A comunicação, portanto, seria um aspecto que permite a abertura ao novo, construído em conjunto com a alteridade. Ao afirmar isso, o autor busca criticar perspectivas individualistas, que tratariam os sujeitos como monológicos, solipsistas e autônomos.

Emprego o termo epistemológico no sentido da língua inglesa. A epistemologia é a teoria do conhecimento. A palavra francesa que melhor corresponde a esse termo é "gnoseológico". Chamo de epistemológico o modelo da comunicação que opera em termos de formação e transição de representações adequadas das propriedades das coisas graças a processos mentais e a práticas de "indiciação" de estados internos (QUÉRÉ, 2018, p. 18).

Desse modo, o momento da interação seria nada mais do que uma mera transmissão de estados já pré-figurados dos sujeitos e de um mundo partilhado por eles. No modelo epistemológico, a comunicação é vista como um desafio cognitivo, cujo "sucesso" estaria ligado à eficiência na codificação e decodificação do signo. 0 "emissor" racionalizaria o conhecimento sobre o mundo em um movimento transmissivo rumo ao "receptor".

Em contrapartida ao que ele chama de perspectiva epistemológica, o sociólogo propõe a adoção de um modelo praxiológico, segundo o qual se pode perceber a sociedade inteira se constituindo pela via das inúmeras interações práticas comunicativas. A comunicação, materializada nas conversações práticas cotidianas, fala de uma dimensão 
global da sociedade: se os sujeitos se constituem no ato comunicativo, o mesmo ocorre com o mundo em que estão inseridos. Para explicar sua tese, Quéré (2018) enumera quatro traços que se opõem à racionalização epistemológica tradicional.

0 primeiro traço se refere à linguagem. Enquanto o modelo epistemológico trataria a ação linguística sob uma perspectiva meramente utilitarista e representacional, a abordagem praxiológica busca mostrar como o sistema simbólico é parte essencial da construção do mundo e da compreensão de quem somos. "Por exemplo, tratando-se de sentimentos, parece que nossa capacidade de formulá-los com a ajuda de um vocabulário [...] transforma sua natureza mesma, na medida em que ela clarifica e que acrescenta sua individualidade" (QUÉRÉ, 2018, p. 32). Desse modo, o autor tenta mostrar como não é possível termos uma realidade comum para além ou fora do âmbito da linguagem.

O segundo traço se refere à formação do espaço público. Quéré (2018) discorda da premissa de que o mundo em comum seja pré-definido. Em oposição, o autor defende que o ser se molda enquanto aparece, quando vem a público no espaço compartilhado pelos sujeitos.

Isto implica, por exemplo, para a comunicação, que o conteúdo mesmo daquilo que se tornou manifesto entre os parceiros não somente não é complemente determinado antes da própria interação, mas também que não existe outra "realidade" do que aquela que é configurada conjuntamente no espaço público (QUÉRÉ, 2018, p. 34, grifo nosso).

O autor explica que mesmo os pontos de vista pessoais estão ancorados em perspectivas coletivas. E, ao se manifestarem, o fazem a partir de discursividades enraizadas grupalmente. Formulamos opiniões a partir do que é partilhado - mesmo a respeito de problemas que afetem apenas a um de nós.

0 terceiro traço, que difere o modelo praxiológico do modelo epistemológico, segundo Quéré (2018), seria o problema da expressão. Enquanto na perspectiva epistemológica, a expressão é uma mera manifestação de uma realidade definida a priori, a nova abordagem evita a separação entre estados internos e os comportamentos externos. Para o autor, o ato de se expressar seria, portanto a "[...] manifestação encarnada nas ações, em objetos expressivos, de um desejo, de uma intenção, de um sentimento, etc., de tal maneira que estes não existam previamente a esta expressão ou independentemente dela" (QUÉRÉ, 2018, p. 36). A intenção, portanto, seria constituída ao longo da interação e a expressão pública de tal intenção formataria também o que será expresso pelos sujeitos. 
Tal afirmação está intimamente ligada ao quarto traço apresentado pelo autor, que diz respeito justamente à intencionalidade. Quéré (2018) não acredita no fato de haver intenções independentes do ato comunicacional. Mesmo que os sujeitos tenham preparado algo anteriormente e desejem sustentar ideias antes da interação, a expressão de tais asserções dependerá do próprio momento interacional, levando em consideração possíveis reações, imprevistos ou mudanças situacionais e emergidas no próprio ato de comunicação - o ajustamento, já citado anteriormente. Em outras palavras, mesmo a própria intenção dependeria da alteridade para se realizar.

Consideraremos que a intenção comunicativa se exprime de maneira encarnada, na busca confusa - em um quadro de interação com o outro ou consigo mesmo - de uma formulação adequada para os pensamentos, ideias, opiniões etc. Esta formulação toma progressivamente forma com a ajuda dos outros, no desenvolvimento do curso da ação conversacional segundo sua temporalidade própria. Longe de ser imediatamente acessível ao sujeito por meio da observação interna, a intenção comunicativa aparece mediada por sua encarnação em uma realização pública (QUÉRÉ, 2018, p. 37).

Ao focar a análise na comunicação em ato, Quéré (2018) não despreza as estruturas sociais, as instituições, enfim, as configurações que ultrapassam o momento interacional. Sobre esse ponto, o autor argumenta que o caráter simbólico do modelo não nega a existência de um ambiente ao redor dos sujeitos. Tal ambiente seria exatamente o quadro de referência, a ordem institucional que guiaria a formulação dos sentidos. A organização da experiência entre atores se daria sob o registro de quadros institucionais mais amplos. E é essa mesma experiência, costurada pelas práticas comunicacionais, que também constitui o contexto no qual o agente social se relaciona. Esse contexto não seria uma ambiência inconsciente ou independente dos sujeitos, mas "[...] definido de maneira contínua por uma atividade adaptativa implicando a cognição, a interpretação, a esquematização etc., no contexto da organização social das ações práticas" (QUÉRÉ, 2018, p. 45).

Sobre o modelo defendido por Quéré, França (2018) argumenta que não existe, no modelo praxiológico, uma dualidade entre o particular e o geral. Para a autora, olhar a comunicação como um aspecto constitutivo leva em conta não apenas a inscrição recortada dos indivíduos, mas o ato comunicacional dando forma a um "[...] andaime de um mundo em construção" (FRANÇA, 2018, p. 100).

Quéré (2018) também não menospreza a assimetria das interações, fruto da força das estruturas sociais de classe e poder. 0 autor propõe perceber outra força que nos regula: 
aquela que nasce da intersubjetividade prática. Tal razão pragmática nos levaria a compreender a nós mesmos e ao outro justamente na ação que é realizada de forma conjunta.

\begin{abstract}
Quando falo de uma perspectiva comum, não me refiro a uma concordância de pensamentos ou opiniões nem a uma convergência de pontos de vista pessoais. Refiro-me ao fato de os parceiros construírem juntos o lugar comum a partir do qual vão momentaneamente se relacionar uns com os outros e com o mundo e organizar suas ações recíprocas. Então, para o modelo praxiológico, a comunicação é essencialmente um processo de organização de perspectivas compartilhadas, sem o qual nenhuma ação e interação se tornam possíveis (QUÉRÉ, 2018, p. 25).
\end{abstract}

Este é um importante ponto a ser destacado para, posteriormente, conectá-lo a Flusser. Após apresentarmos os detalhes do modelo praxiológico, chama a atenção, particularmente, a relação entre interlocutores e o modo pelo qual eles elaborariam, um mundo em comum, considerando a não necessariamente de concordância.

A intersubjetividade prática, ou seja, a visão de que somos partes de uma coletividade que se organiza pragmaticamente e é mediada pelos dispositivos interacionais (BRAGA, 2006; 2011), ajuda a entender a comunicação como uma "modelagem mútua", uma "cumplicidade coordenada" e uma "ação conjugada" da esfera social - para usarmos as palavras do próprio Quéré (2018).

Se a intersubjetividade prática diz respeito às relações que se estabelecem na práxis cotidiana e, a partir daí, na construção do mundo social, é preciso ir adiante na compreensão desse momento do estar-com, do encontro de alteridades e do ato de coexistir. Ancorandose nas discussões de Mead (1934), Quéré (2018, p. 39) explica justamente que a ação dos indivíduos "[...] consiste em adotar o ponto de vista do outro sobre si, seja a do outro particular com quem se interage, seja do outro generalizado acessível pela imaginação". É exatamente nesse ponto que destacamos o valor heurístico dos estudos sobre empatia a fim de enriquecer a compreensão do modelo praxiológico da comunicação. E é por esse motivo que acreditamos ser importante resgatar, aqui, as perspectivas já apresentadas e que se debruçam sobre tal noção, especialmente Flusser (1994a, 1994b, 1998, 2012). 


\section{Perspectivas que se cruzam}

Pensar sobre empatia ajuda a entender, de forma mais apurada, algumas nuances concernentes ao modelo praxiológico proposto por Louis Quéré (2018). Chama a atenção o fato de que os teóricos mencionados, mesmo que não intencionalmente, forneçam elementos importantes para pensar a comunicação em uma perspectiva processual, atingindo camadas filosóficas e epistemológicas ao se refletir sobre o ato comunicacional.

Enquanto Quéré (2018) percebe as subjetividades e as formas de sociabilidade se constituindo no bojo das interações, Flusser (2018) encara a comunicação como um momento transformador. Não por acaso, Flusser considera a própria noção de cultura dentro do âmbito comunicacional. Outro ponto de interseção é quando Flusser também sublinha que, na contemporaneidade, ocorre o rompimento do que ele denomina de "cápsula do eu" - uma visão autonomista e solipsista dos sujeitos que é desconstruída na atual era de rede (FELINTO; SANTAELLA, 2012). A potência do momento interacional dos indivíduos encontra, aqui, um importante eco com o modelo praxiológico, especificamente ao destaque dado por Quéré aos sentidos que se constituem e se expressam em coletividade, em espaços públicos ou em rede na esfera relacional dos sujeitos.

Mesmo que Flusser (1998) esteja se referindo, prioritariamente a uma sociedade telemática, em que tecnologias, objetos e humanidades interagem entre si, não podemos perder de vista que seu pensamento sempre retorna para o sujeito social e seus processos de comunicação. O autor aciona a imagem do molusco (FLUSSER, 2012) como metáfora conceitual para chamar a atenção ao ato interlocutório que permite o atravessamento entre culturas, o encontro de ambiências e o confronto de alteridades, de modo que cada ator se (re)constitua a partir de uma experiência empática. Também no modelo praxiológico, a organização da experiência e a intencionalidade dos sujeitos tomam forma justamente em interação.

A atividade contínua de adaptação e interpretação (QUÉRÉ, 2018) pode ser associada à multidimensionalidade da empatia na visão de Lou Agosta (2014). Se para o autor, é na relação que emerge a alteridade, é preciso entender o poder do choque de subjetividades, do confronto com um outro que não sou eu. Não aleatoriamente, Agosta (2014, p. 3) usa as expressões "empatia e empatia interpessoal".

Assim, relembramos porque a noção de empatia precisa se libertar do raso sentido da consensualidade. É necessário que haja o elemento da diferença na experiência empática, da mesma forma que a comunicação se realiza na variedade. Se assim não fosse, no ato 
comunicacional, teríamos apenas repetição, processo imitador, previsível e existente $a$ priori. Mesmo quando os atores se encontram em situação relativamente consensual, sempre existirá a ipseidade que distingue os interagentes. Quando falamos, não proferimos nossos discursos para um espelho, mas sim para uma consciência outra que, justamente por não ser a mesma, manifesta sua singularidade no mundo em comum.

Quando as consciências em interação são uníssonas, a comunicação perde sua potência: o consenso já está alcançado, os sentidos estão dados e a dimensão criativa deixa de emergir. A empatia é mais do que uma concordância ou um encontro de racionalidades afins, mas considera, ainda, o sair de si em direção ao outro com o objetivo de construir pragmaticamente o mundo.

Apesar desse outro ser, um ingrediente importante no momento da interação, ele mesmo não deixa de existir, não desaparece no ato comunicacional. Aqui, outro destaque deve ser feito. Tanto no modelo praxiológico quanto nas abordagens de empatia citadas, o sujeito em comunicação, que se inclina em direção à alteridade, sofre um processo de apagamento. Ao contrário, ele perpassa um dinamismo de constituição.

Ao acionar a fábula do cefalópode das profundezas do mar, Flusser (2012) apresenta justamente isso: a necessidade de o ser humano se projetar, de se perder para se encontrar. É na diferença radical do Vampyroteuthis que eu me descubro. É no espelho do outro que vejo meu próprio reflexo.

Em todos esses lugares, o Vampyroteuthis vai surgindo como o nosso próprio espelho. Como antípoda nosso, no qual todos os nossos aspectos são invertidos. Pois contemplar tal espelho, a fim de reconhecer-se nele, e a fim de poder alterar-se graças a tal reconhecimento, é o propósito de toda fábula, inclusive desta (FLUSSER, 2012, p. 134).

Quéré (2018) mostra como a adoção do ponto de vista do outro, mesmo que seja o Outro Generalizado (MEAD, 1934), permite me construir e me posicionar enquanto sujeito. Ter esse encontro com o outro, como uma experiência ativa e frutífera, também é um dos argumentos centrais no pensamento de Adriana Cavarero (2016), especificamente quando a autora cita o quadro de Leonardo da Vinci. Enquanto a Virgem Maria se inclina na direção do filho, tal movimento maternal não significa um apagamento da mãe em relação à criança. Em seu eixo de projeção, Maria constrói também sua singularidade, sua condição de indivíduo. É justamente na inclinação que ela se constitui enquanto sujeito da história e, de certa forma, 
inclina-se sobre si mesma. Também, ao virar-se para a mãe, na situação de dependência e vulnerabilidade, o filho se faz indivíduo.

\begin{abstract}
Incorporando o outro na relação com o recém-nascido sobre o qual ela se inclina, a mãe não só confirma o caráter relacional e anti-vertical da cena, mas também, ao predispô-lo a uma ética altruísta, exige que ela seja entendida em termos de uma dependência. Vale a pena repetir que o principal problema é como persuadir o eu, orgulhosamente encapsulado em sua verticalidade, a renunciar à sua reivindicação de autonomia e independência (CAVARERO, 2014, p. 102). ${ }^{6}$
\end{abstract}

Desse modo, a linha imaginária traçada entre os três atores do quadro revela o caráter relacional do ato, acentuando o eixo que costura a interação entre Maria e a criança e Maria e Ana. Ao mesmo tempo, e aqui retomamos o pensamento de Flusser (1998), a análise da obra tenta sair de uma perspectiva de um sujeito autônomo, encapsulado, preso em si mesmo para um indivíduo que se relaciona em rede enquanto condição de vida. Ao discorrer sobre os gestos, Flusser (1994a) defende a ideia de que a gestualidade não tem a ver só com um movimento corporal, mas com a maneira pela qual lidamos com o mundo e com o outro. 0 gesto empático me desloca, a partir de uma alteridade. A comunicação é a possibilidade de compreendermos (ou até mesmo assumirmos) este outro lugar.

Ora, é exatamente essa a visão praxiológica da comunicação. A ultrapassagem de um sujeito epistemológico/cognitivo para um sujeito em relação é um dos pontos centrais do modelo proposto por Louis Quéré. Tanto para o autor francês quanto para os teóricos apresentados aqui, a alteridade e a diferença se mostram não apenas como fenômenos a serem observados, mas como ingredientes essenciais para nossa (sobre)vivência. Só conseguimos estar em sociedade porque sabemos da existência de outras subjetividades (mesmo discordantes) que possuem expectativas sobre nós e que dividem conosco um modelo social regido por regras, instituições e redes compartilhadas de interação.

\title{
Considerações finais
}

Este ensaio buscou entender como diferentes perspectivas podem enriquecer a visão processual da comunicação enquanto objeto e campo de estudo. A intersubjetividade - ou

\footnotetext{
${ }^{6}$ Tradução livre de "Embodying the other in relation to the new-born over whom she leans, the mother not only confirms that scene's relational and antivertical character, but also, by predisposing it to an altruistic ethics, requires that it be understood in terms of dependence. It is worth repeating that the main problem is how to persuade the self, proudly encapsulated in its verticality, to renounce its claim to autonomy and independence".
} 
intersubjetividade empática, como afirma Pinotti (2010) - seria a chave hermenêutica que ligaria as distintas perspectivas e ressaltaria o caráter dialógico das interações. Isso se torna possível ao acionarmos o modelo praxiológico de Louis Quéré e a empatia na construção do outro e do si, em Vilém Flusser, para os processos comunicacionais.

O que nos interessou aqui foi reforçar a importância de abandonar tendências inocentes que ora estudam a interação comunicativa como um momento estritamente consensual, ora encaram os fenômenos comunicacionais como lugares de manifestações estritamente agonísticas e conflituosas.

Acreditamos que um dos principais valores dos estudos da intersubjetividade, tão presente nas obras de Quéré e, indiretamente, de Flusser e outros autores que abordam a temática da empatia, é mostrar as zonas híbridas, o trânsito de sentidos, os momentos em que atores com códigos diferentes precisam se comunicar com seus respectivos pilares de referência (FLUSSER, 1998). A intersubjetividade prática/empática permite visualizar percepções de mundo sob o paradigma relacional e encarar a existência imersa numa grande teia que conecta outras diferenças.

Ao concluir este ensaio, gostaríamos de fazer uma ressalva. Apesar dos pontos de intercessão apresentados, Quéré e Flusser estão conectados a fios teóricos distintos. Embora tenha transitado por vários ramos do conhecimento, Flusser aborda questões filosóficas e ontológicas, incluindo um forte acionamento de elementos ficcionais e de propostas metafóricas (não necessariamente conceituais) de pensamento e da consciência de si. Já Louis Quéré, enquanto sociólogo, também debate filosoficamente a comunicação, porém marca o sujeito dentro de uma perspectiva social. Seu modelo praxiológico tem como intenção ser uma "matriz paradigmática" (FRANÇA, 2018, p. 91), ou seja, a proposição de uma teoria social e comunicacional.

0 modo como ambos os teóricos olham para atores sociais tem suas particularidades. 0 sujeito em Flusser assume um caráter existencial-psicológico e, portanto, pode ser metaforicamente representado. Por isso mesmo, a interação com seres não humanos é admitida no arcabouço flusseriano. Já em Quéré, o sujeito é social e histórico por natureza. Os atores não-humanos são reconhecidos como agentes dotados de significação, mas Quéré (2018, p. 86) acredita que eles são meios ou mediações “[...] indispensáveis à concretização das intenções e tornam a cooperação possível e realizável". Em outras palavras, a interação comunicativa sobre a qual ele se debruça é, de fato, aquela realizada entre humanos. 
Não nos aprofundaremos na discussão de tais diferenças, mas gostaríamos apenas de marcar os limites entre as duas perspectivas e reafirmar que tentamos realizar, neste ensaio, um exercício desafiador de aproximar ambas as matrizes, apontando para permanentes desdobramentos em nossa reflexão. Questionamos, assim, como se dá o caráter de empatia em tempos de individualismo tão exacerbado e, ao mesmo tempo, de tantos encontros na virtualidade. Como pensar a dialogicidade em um momento no qual a técnica ocupa um papel protagonista? Como a desconstrução da "cápsula do eu" se comporta em um mundo permeado por tecnologias digitais? Como é possível visualizar a construção do self no momento em que me inclino para o outro? Entendemos que a intersubjetividade prática, a alteridade e a empatia se colocam como operadores conceituais interessantes para esses e outros problemas do pensamento comunicacional.

\section{Referências}

AGOSTA, Lou. A rumor of empathy: reconstructing Heidegger's contribution to empathy and empathic clinical practice. New York: Palgrave Macmillan, 2014.

BRAGA, José Luiz. A sociedade enfrenta sua mídia: dispositivos sociais de crítica midiática. São Paulo: Paulus, 2006.

BRAGA, José Luiz. Dispositivos interacionais. In: ENCONTRO ANUAL DA COMPÓS, 10., 2011, Porto Alegre. Anais [...]. Porto Alegre: Universidade Federal do Rio Grande do Sul, 2011. p. $1-15$.

CAVARERO, Adriana. Inclinations: a critique of rectitude. Stanford: Stanford University Press, 2016.

DICIONÁRIO de Chile. Santiago: Valentin, 1998. Disponível em: http://etimologias.dechile.net/?empati.a. Acesso em: 20 abr. 2020.

FELINTO, Erick; SANTAELLA, Lucia. 0 explorador de abismos: Vilém Flusser e o póshumanismo. São Paulo: Paulus, 2012.

FLUSSER, Vilém. Ficções filosóficas. São Paulo: Edusp, 1998.

FLUSSER, Vilém. Filosofia da caixa preta: ensaios para uma futura filosofia da fotografia. Rio de Janeiro: Relume Dumará, 2002.

FLUSSER, Vilém. Los gestos: fenomenología y comunicación. Barcelona: Herder, 1994a.

FLUSSER, Vilém. 0 mundo codificado: por uma filosofia do Design e da Comunicação. São Paulo: Cosac Naify, 2007.

FLUSSER, Vilém; BEC, Louis. Vampyroteuthis infernalis. Coimbra: Annablume, 2012. 
FLUSSER, Vilém. Vom Subjektzum Projekt. Menschwerdung. Schriften, Bd, v. 3, 1994b.

FRANÇA, Vera. Discutindo o modelo praxiológico da comunicação: controvérsias e desafios da análise comunicacional. In: FRANÇA, Vera; SIMÕES, Paula. (org.). 0 modelo praxiológico e os desafios da pesquisa em comunicação. Porto Alegre: Sulina, 2018. p. 89-117.

HABERMAS, Jürgen. Mudança estrutural da esfera pública: investigações quanto a uma categoria da sociedade burguesa. Tradução, Flávio R. Kothe. Rio de Janeiro: Tempo Brasileiro, 1984.

HALL, Stuart. Codificação/decodificação. In: HALL, Stuart; SOVIK, Liv. (org.). Da diáspora: identidades e mediações culturais. Belo Horizonte: UFMG, 2003. p. 387-404.

HAYLES, N. Katherine. Speculative æsthetics and object-oriented inquiry (ooi). In: ASKIN, Ridvan et al (Ed.). Speculations: a journal of speculative realism, v. 5, 2014. p. 158-79.

MEAD, George Herbert. Mind, self and society. Chicago: University of Chicago Press, 1934.

PINOTTI, Andrea. Empathy. In: SEPP, Hans Rainer; EMBREE, Lester (Ed.). Handbook of phenomenological aesthetics. New York: Springer, 2010. p. 93-98.

QUÉRÉ, Louis. De um modelo epistemológico da comunicação a um modelo praxiológico. In: FRANÇA, Vera; SIMÕES, Paula. (org.). 0 modelo praxiológico e os desafios da pesquisa em comunicação. Porto Alegre: Sulina, 2018. p. 15-48.

QUÉRÉ, Louis. D'un modèle épistémologique de la communication à un modèle praxéologique. In: BEAUD, Paul; FLICHY, Patrice (Ed.) Réseaux. CommunicationTechnologie-Société, v. 9, n. 46-47, 1991. p. 69-90.

\title{
The theory of empathy theory and the praxiological model of communication: (unlikely) approaches between Flusser and Quéré
}

\begin{abstract}
The essay aims to compare the notion of empathy in Vilém Flusser's viewpoint to the praxiological model of communication, developed by Louis Quéré. Such definitions are identified here from some perspectives that focus on the importance of intersubjectivity, the interaction between subjects as well as the process of building the individual by leaning towards the otherness. To do so, we use these two theorists, from different schools and timeframes, in order to understand how a "theory of empathy" can be managed as a theoretical framework that may contribute to the praxiological model of communication. We conclude that, despite conceptual differences, both theorists see the amalgamation of human
\end{abstract}


experience in the relationship with the otherness and within intersubjectivity.

\section{Keywords}

Empathy. Alterity. Praxiological model. Intersubjectivity.

Recebido em 28/04/2020

Aceito em 23/07/2020 